\title{
PRODUCTION POTENTIAL AND ECONOMIC FEASIBILITY OF MEDICINAL PLANT PRODUCTION IN UKRAINE
}

\begin{abstract}
The article examines some aspects of the current state of production of medicinal plants in Ukraine. The analysis of the functioning of enterprises in this industry in terms of purely medicinal, essential oil and spicy crops is made. Characteristic tendencies of production of medicinal plants are revealed. The main reasons for the reduction of the number of enterprises in Ukraine engaged in the cultivation of medicinal plants are outlined. The emphasis is placed on the sown areas of medicinal plants in Ukraine, production volumes, yield levels and sales volumes. As a result of the analysis of groupings by sown area of medicinal crops, clear dependences on this factor of indicators of economic efficiency of production of medicinal plants in agricultural enterprises were revealed. The factors that determine the economic feasibility of production of this product are identified.
\end{abstract}

Keywords: medicinal plants, production, enterprise, economic efficiency.

\section{INTRODUCTION}

The use of the healing properties of plants is connected to the development of human civilization, science and industry. Numerous expeditions of researchers, development of trade relations and travels, exchange of plants between different countries contributed to the study and mastering of medicinal plants. A significant surge in interest in medicinal plants arose during the First World War, when people became sure that synthetic chemicals were often harmful to health. Gradually, attention to medicinal plants increased. Nowadays, medicinal plants make a significant contribution to healthcare, provision of livelihoods for certain segments of the population and are among the most valuable non-woody plant resources. Many scientists today note that medicinal plants have great potential to contribute to economic growth and poverty reduction in developing countries - Sri Astutik, Jürgen Pretzschand Jude Ndzifon Kimengsi (2019), Yebirzaf Yeshiwas (2018).

Medicinal plants are a valuable raw material for the manufacture of medicines. Thus, according to the International Union for Conservation of Nature and the World Wildlife Fund, there are now between 50,000 and 80,000 species of medicinal plants in the world that are used for medicinal purposes. Up to $80 \%$ of people and $90 \%$ of pets in developing countries are completely dependent on herbal medicines in primary health care, and in developed countries more than $25 \%$ of medicines are derived from wild medicinal plants

\footnotetext{
1 Tetiana Mirzoieva, PhD, Prof. I.N. Romanenka Department of Economy of Enterprise, National University of Life and Environmental Sciences of Ukraine; e-mail: mirzoeva2018@ukr.net. ORCID: 0000-0002-0034-6138.
} 
(Shi-Lin Chen, Hua Yu, Hong-Mei Luo, Qiong Wu, Chun-Fang Li, André Steinmetz (2016), Hamilton A.C. (2004).

A significant increase in the market for medicinal plants and herbal products worldwidehave been seen duringthe last three decades. According to the FAO, world production of medicinal plants, including essential oils and spices, is currently estimated at 330 million tons and covers 77 million hectares (Mebrahtu Hishe, Zemede Asfaw, Mirutse Giday, (2016), Dimitrios Argyropoulos, (2019). Nowadays the significant role of medicinal plants in human life is also confirmed by the fact that the World Bank predicts that by 2050, the market or medicinal plants will be estimated at 5 trillion dollars, and the World Health Organization is conducting a program called «Health for All, relying on the use of medicinal plants» (Jafari, Ahmadian, Tarhani (2017), Shabbara, Heba, AbdEL-Fatah, Karima A. Mohamed and Haitham Hassan (2017).

However, despite the rapid development of production of medicinal plants in the world and the current demand for them, there are a number of problems in this area that need to be solved. Thus, nowadays, a large part of medicinal plants is endangered due to uncontrolled collection in the wildnature. That is why, there is a question of further development in the cultivation of medicinal plants in specialized enterprises and households. The development of medicinal plant production in developing countries also needs huge attention. For example, in Ukraine, along with intensively developed agricultural production, the sphere of production of medicinal plants is at the stage of formation. Therefore, the purpose of this study is to investigate the current state of production of medicinal plantsin Ukraine (including spicy and essential oils) and its economic feasibility.

\section{METHODOLOGY OF RESEARCH}

The study was of an applied nature and was conducted using a descriptive-analytical method and a method of statistical grouping. In particular, as a result of the analysis of groupings by sown area of medicinal crops, clear dependences on this factor of indicators of economic efficiency of production of medicinal plants in agricultural enterprises operating in different regions of Ukraine were revealed. The study covered agricultural enterprises operating in agriculture of Ukraine and reporting to state statistical bodies as producers of medicinal plants, including spicy and essential oils.

\section{RESULTS}

First of all, it's necessary to note that in 2018, compared to 2017, the number of agricultural enterprises that according to statistics were engaged in the cultivation of medicinal plants in Ukraine decreased by $33 \%$ or 77 units. This phenomenon can be explained by several reasons: 1) the market of medicinal plants in Ukraine and in the world is unstable, as the demand for medicinal crops changes every year; 2) in Ukraine there are no established sales channels for medicinal plant raw materials; 3) the production of medicinal plants is a technologically complex process; 4) the trend of recent years in Ukraine is that a large number of agricultural producers do not report to state statistics bodies or submit incomplete reports on their work. We consider that these and a number of other factors have influenced the reduction in the number of agricultural enterprises engaged in the production of medicinal plants in Ukraine according to state statistics. Accordingly, their number in 2018 amounted to 157 units. 
It should be noted that the presented number of enterprises that grow medicinal plants for a country like Ukraine is simply meager. For comparison - in Europe, more than 36 thousand companies are engaged in the cultivation of medicinal and aromatic plants on an area of over 200 thousand hectares. Most of them are located in France (52,0 thousand hectares), Poland (30,0 thousand hectares), Spain (27,8 thousand hectares), Bulgaria (16,8 thousand hectares), Croatia (8,5 thousand hectares), The Czech Republic (7,2 thousand hectares), Italy (7,2 thousand hectares), Greece (6,8 thousand hectares) and Austria (4,1 thousand hectares). In Germany, medicinal and aromatic plants are grown by 750 farmers on a total area of 12,240 hectares. Chamomile, anise, fennel, flax, mint and milk thistle are considered to be the most valuable medicinal plants in Europe (Stelter, Oehme, Daebeler, 2017).

The analysis of the current state of production of medicinal plants in Ukraine showed that Ukrainian agricultural enterprises operating in this industry in 2017-2018 in the largest volumes produced essential oil crops, the least volumes - spicy (Table 1) - and both are medicinal. In turn, in the totality of essential oil crops in the study period, the largest areas were allocated for the cultivation of such a crop as sage and, accordingly, this crop was in the top in terms of production. Previous research (Mirzoieva, 2018) indicated that in 2017, Ukraine imported sage, so it is likely that Ukrainian producers have responded to the current demand for this crop. In the aggregate of purely medicinal plants, chamomile was the leader in terms of sown area in 2018, and valerian in terms of production volumes. In the totality of spicy crops, the undisputed leader in 2017-2018 was coriander. It should be noted that since 2017, Ukraine is among the TOP-5 world leaders in coriander exports (Ovcharenko, 2017). However, in terms of cash receipts from the export of this culture, Ukraine ranks only 11th in the world. As for the geography of exports, the main buyers of Ukrainian coriander are India (30\%), Sri Lanka (20\%) and Indonesia (10\%). The shares of these countries in the structure of foreign exchange earnings are slightly lower $-27 \%, 17 \%$ and $9 \%$ respectively. Together, the top three account for about $60 \%$ of Ukrainian supplies and $53 \%$ of revenues from their implementation (Deina, 2019).

In turn, one of the most popular crops in Ukraine and the world is chamomile (Mirzoieva, 2018). The advantages of chamomile production are also that in the process of processing almost all parts of the plant are used - flowers, pollen and petals, seeds, stems for straw. Some experts say that it is especially profitable to sell chamomile abroad: you can get about 8 US dollars per kilogram, which is quite a good price for Ukraine. (Dachnytsia, 2018). However, you can get a lot of money for chamomile if you sow a varietal crop, follow the technology of production and drying. At the same time, as revealed in the study, most Ukrainian producers are wary of the production of chamomile, as, firstly, the culture is quite risky to grow, and secondly, the leader in the production of chamomile in the world is Egypt. The main advantages of this country are cheap labor and the ability to harvest 3-4 crops a year.

In the structure of medicinal plants by species, in addition to chamomile, a significant share is occupied by the group of «other medicinal plants». Due to the fact that Ukrainian medicinal plants are currently growing, this group is quite powerful and includes a large number of crops - immortelle, herd, calendula, plantain, dandelion, echinacea, rhodiola rosea, milk thistle, basil etc.

In general, the analysis of the production of medicinal, spicy and essential oil crops in agricultural enterprises of Ukraine in terms of sown areas, production volumes and yield levels shows that this area is developing intensively. The number of enterprises in this 
industry decreased by $33 \%$ in 2018 and, accordingly, the sown area under medicinal crops decreased significantly. On the other hand, the production of purely medicinal plants increased by $11,8 \%$, and of essential oils - by $20,2 \%$. In terms of a number of crops, the yield has increased.

Table 1. Production of medicinal, spicy and essential oil plants in the studied enterprises in 2018

\begin{tabular}{|c|c|c|c|c|c|c|c|c|}
\hline & \multicolumn{2}{|c|}{$\begin{array}{l}\text { Number } \\
\text { of farms }\end{array}$} & \multicolumn{2}{|c|}{$\begin{array}{c}\text { The sowing area, } \\
\text { ha }\end{array}$} & \multicolumn{2}{|c|}{ Production, $\mathrm{c}$} & \multicolumn{2}{|c|}{ Yield, c/ ha } \\
\hline & 2017 & 2018 & 2017 & 2018 & 2017 & 2018 & 2017 & 2018 \\
\hline Medicinal plants - total & 73 & 63 & 4930,0 & 4281,88 & 37539,2 & 41968,26 & 7,6 & 9,8 \\
\hline Chamomile & 17 & 10 & 504,5 & 332,20 & 4415,2 & 1175,57 & 8,8 & 3,5 \\
\hline Valerian & 4 & 4 & 42,2 & 37,03 & 1296,7 & 1319,60 & 30,7 & 35,6 \\
\hline Dog nettle & 4 & 2 & 23,0 & 13,00 & 344,8 & 186,50 & 15,0 & 14,4 \\
\hline Calendula & 4 & 1 & 8,0 & 5,0 & 33,5 & & 4,2 & 0,00 \\
\hline Other medicinal plants & 41 & 38 & 1181,4 & 1095,1 & 11424,4 & 5826,4 & 9,7 & 11,9 \\
\hline Spices - total & 47 & 20 & 3141,7 & 1355,59 & 23278,8 & 7232,30 & 7,4 & 5,3 \\
\hline Anise and thistle & 3 & 1 & 18,6 & 1,00 & 115,1 & 0,50 & 6,2 & 5,3 \\
\hline Coriander & 36 & 13 & 2792,5 & 1304,85 & 22189,6 & 7003,40 & 7,9 & 0,5 \\
\hline Fennel & 3 & 3 & 47,3 & 31,00 & 92,1 & 20,80 & 1,9 & 5,4 \\
\hline Thyme & 3 & 3 & 1,8 & 5,62 & 59,3 & 111,20 & 33,9 & 0,7 \\
\hline \begin{tabular}{|l|}
$\begin{array}{l}\text { Essential oil plants - } \\
\text { total }\end{array}$ \\
\end{tabular} & 114 & 74 & 8496,1 & 4810,93 & 53714,2 & 64558,01 & 6,3 & 19,8 \\
\hline Sage & 12 & 13 & 631,3 & 747,50 & 9152,2 & 35171,40 & 14,5 & 13,4 \\
\hline Mint & 12 & 9 & 41,8 & 25,77 & 623,6 & 952,01 & 14,9 & 47,1 \\
\hline Lavender & 1 & 1 & 1,0 & 1,00 & 0,0 & 0,50 & 0,0 & 36,9 \\
\hline Fennel & 5 & 7 & 191,5 & 168,70 & 383,4 & 194,73 & 2,0 & 0,5 \\
\hline
\end{tabular}

Source: Official site of the State Statistics Serviceof Ukraine (2019; http://www.ukrstat. gov.ua) authors' own depiction.

It can be assumed that there are specialized enterprises in the industry that invest in the development of medicinal crops.

For a more profound analysis and in order to divide the complex, heterogeneous set of Ukrainian enterprises producing medicinal plants in 2018 into homogeneous internally, but significantly different groups, all studied enterprises were divided into 5 groups depending on the sown area of medicinal plants - from less than 10 hectares to more than 100 hectares (Table 2). It turned out that most enterprises in the total number of studied, namely 44 or $30,3 \%$ of medicinal plants have 40,1-100 hectares and they account for $27,2 \%$ of the sown area. The second largest group of enterprises has up to 10 hectares of medicinal plants - 36 out of 145 or $24,8 \%$ of them and these enterprises account for 179,5 hectares or $1,7 \%$ of all sown areas of medicinal plants. At the same time, it was found that 27 farms $(18,6 \%$ of the total number of surveyed enterprises) that use more than 100 hectares for growingmedicinal plants account for 6495,4 hectares or $62,2 \%$ of the total sown area under medicinal plants in the studied enterprises. We believe that this is evidence that:

- firstly, in the field of Ukrainian medicinal plant growing, a core of large specialized enterprises has been formed; 
- secondly, a number of small and medium-sized enterprises operate among Ukrainian producers of medicinal plants. In addition, we assume that a significant part of agricultural enterprises use medicinal plants in crop rotations or are engaged in the cultivation of medicinal plants as a side activity;

- thirdly, a certain segment in this market is occupied by mini-farms.

As for the species ratio of medicinal plants, the distribution used by the State Statistics Service of Ukraine was taken as a basis. In particular, during the grouping, purely medicinal plants, spicy and essential oils were identified

Table 2. Distribution of farms by the total sown area of medicinal, spicy and essential oil plants, $2018 \mathrm{p}$.

\begin{tabular}{|c|c|c|c|c|c|c|}
\hline \multirow[b]{2}{*}{ Indicator } & \multicolumn{5}{|c|}{ Groups by sown area of plants } & \multirow[b]{2}{*}{ All farms } \\
\hline & up to 10 & $10,1-20$ & $20,1-40$ & $40,1-100$ & $\begin{array}{c}\text { more } \\
\text { than100 }\end{array}$ & \\
\hline Number of farms & 36 & 14 & 24 & 44 & 27 & 145 \\
\hline \multicolumn{7}{|c|}{ Sowing area, ha } \\
\hline Total & 179,5 & 238,5 & 688,6 & 2846,3 & 6495,4 & 10448,4 \\
\hline including medicinal plants & 93,8 & 76,5 & 429,3 & 787,0 & 2895,2 & 4281,9 \\
\hline Spices & 34,4 & 40,0 & 30,0 & 192,3 & 1058,9 & 1355,6 \\
\hline essential oils & 51,2 & 122,0 & 229,3 & 1867,0 & 2541,4 & 4810,9 \\
\hline \multicolumn{7}{|c|}{ The sown area averages 1 farm, ha } \\
\hline Total & 5,0 & 17,0 & 28,7 & 64,7 & 240,6 & 72,1 \\
\hline including medicinal plants & 2,6 & 5,5 & 17,9 & 17,9 & 107,2 & 29,5 \\
\hline Spices & 1,0 & 2,9 & 1,3 & 4,4 & 39,2 & 9,3 \\
\hline essential oils & 1,4 & 8,7 & 9,6 & 42,4 & 94,1 & 33,2 \\
\hline \multicolumn{7}{|c|}{ Species ratio, $\%$} \\
\hline medicinal plants & 42,7 & 31,9 & 33,4 & 25,2 & 31,2 & 29,8 \\
\hline Spices & 13,1 & 24,8 & 17,8 & 19,6 & 18,7 & 19,0 \\
\hline essential oils & 44,2 & 43,3 & 48,8 & 55,2 & 50,1 & 51,3 \\
\hline \multicolumn{7}{|c|}{ Production, c } \\
\hline pices & 206 & 544 & 20 & 768 & 5695 & 7232 \\
\hline Medicinal plants & 987 & 452 & 3741 & 7181 & 29606 & 41968 \\
\hline essential oils & 177 & 1069 & 641 & 15803 & 46868 & 64558 \\
\hline \multicolumn{7}{|c|}{ Yield, c/ha } \\
\hline medicinal plants & 10,5 & 5,9 & 8,7 & 9,1 & 10,2 & 9,8 \\
\hline Spices & 6,0 & 13,6 & 0,7 & 4,0 & 5,4 & 5,3 \\
\hline essential oils & 3,5 & 8,8 & 2,8 & 8,5 & 18,4 & 13,4 \\
\hline
\end{tabular}

Source: Official site of the State Statistics Serviceof Ukraine (2019; http://www.ukrstat. gov.ua) authors' own depiction.

In connection with the identified factors, we consider it appropriate in the study of medicinal plants in Ukraine to consider the following main groups of enterprises - large, medium, small and small-scale - mini-farms. The average size of sown area in large enterprises is 240,6 hectares, in medium 64,7 , and in the so-called mini-farms $-5,0$. As revealed in the study, in 2018, Ukrainian producers of medicinal crops, the largest sown 
area was allocated for essential oil plants $-46,1 \%$ in total in all studied enterprises, in second place $-41,0 \%$ purely medicinal plants and in third place for sown areas $-13,0 \%$ of spicy crops (Table 2). This is evidence of the application of diversification of production by Ukrainian producers.

As for the volume of production, the analysis shows that large, medium and small enterprises are in the lead in the production of essential oils and medicinal plants. Small-scale enterprises with sown areas of up to 10 hectares also specialize in the production of purely medicinal plants. By the way, the yield of medicinal plants in the groups of the studied enterprises is the highest in mini-farms with a sown area of up to 10 hectares. In particular, if in the group of large enterprises the yield of purely medicinal plants was 10,2 c/ha in 2018 , in the group of small enterprises even slightly higher - 10,5. In terms of spicy crops, the yield is the highest in small enterprises with a sown area of 10 to 20 hectares 13,6 , and for essential oil crops the highest yields were obtained in 2018 by large enterprises -18 , c/ha.

According to world experience, the vast majority of small and small-scale farms are family farms and higher crop yields are a typical phenomenon for them. Thus, experts note that, as a rule, family farms are focused on high yields, and large agricultural enterprises, primarily on commercial efficiency. Thus, agricultural farms have a higher income of 1 ha, and family farms in developed countries grow more massofaproduct per 1 ha (Markytanenko, 2018).

The last is due to the fact that careful cultivation by the family of their own land almost always gives a better result than the cultivation of employees - someone else's land. World long-term experience shows that: 1) a smaller area is usually cultivated more carefully than a larger one; 2) no mechanization of labor is able to compensate for the difference in yield; 3 ) the yield of the farm has a direct inverse dependence on the area of agricultural land in its ownership - the smaller the area of the mini-farm, the higher the yield of crops. As revealed during the study, these patterns are inherent in the field of medicinal plant growing in Ukraine.

In the field of sales of purely medicinal plants, large enterprises are in the lead - 12896 centners in 2018 or $74,5 \%$ of all sold products, which is due primarily to the largest sown areas and production volumes in this group (Table 3). In second place in terms of sales medium-sized enterprises. The fact that most medicinal plants are sold by large and medium-sized enterprises can also be explained by the fact that they are specialized enterprises. This means that they have well-established production processes, so they achieve high product quality and, consequently, are more attractive to wholesale buyers. Some differences between production volumes and sales volumes in all studied groups of enterprises attract attention. Thus, in the group of small-scale farms in 2018, 987,0 c of medicinal plants were produced, and only $30 \mathrm{c}$ were sold. In all other groups of enterprises, sales of medicinal plants are also lower than production. This can be explained by several reasons. First, the manufactured products could not be sold because of low quality; secondly, the products could not be sold due to unfavorable market conditions and were left in storage; third, enterprises themselves produce the final product (herbal fees, teas etc.) and sell it, not raw materials.

It should be noted that in some years the level of marketability in the field of medicinal crops may exceed production. This can also be explained by several reasons: first, manufacturers sell products produced in previous periods; secondly, the products made by own forces and accepted by various produrers are directed on realization. In this context, it 
is worth mentioning one of the advantages of medicinal plants - grown, but not sold products can be stored for up to three years. During this period, medicinal plant raw materials, when stored properly, will not lose their properties, and the manufacturer will be able to wait for favorable market conditions.

Table 3. Distribution of farms* by sown area of medicinal plants in 2018

\begin{tabular}{|c|c|c|c|c|c|c|}
\hline \multirow{2}{*}{$\begin{array}{c}\text { Groups by } \\
\text { area of } \\
\text { medicinal } \\
\text { plants }\end{array}$} & \multirow{2}{*}{$\begin{array}{c}\text { Number } \\
\text { of farms }\end{array}$} & $\begin{array}{c}\text { Average area } \\
\text { of medicinal } \\
\text { plants per } \\
\text { 1 farm, ha }\end{array}$ & Area, ha & $\begin{array}{c}\text { Production, } \\
\text { c }\end{array}$ & $\begin{array}{c}\text { Yield, } \\
\text { c / ha }\end{array}$ & $\begin{array}{c}\text { Sales } \\
\text { volume, c }\end{array}$ \\
\hline до 10 & 17 & 6 & 93,8 & 987,0 & 10,5 & 30 \\
\hline $10,1-20$ & 6 & 16 & 96,1 & 867,8 & 9,0 & 843 \\
\hline $20,1-40$ & 16 & 28 & 449,4 & 3764,4 & 8,4 & 787 \\
\hline $40,1-100$ & 12 & 62 & 747,3 & 6742,6 & 9,0 & 2752 \\
\hline більше 100 & 12 & 241 & 2895,2 & 29606,5 & 10,2 & 12896 \\
\hline All farms & 63 & 68 & 4281,9 & 41968,3 & 9,8 & 17308 \\
\hline $\begin{array}{l}\text { Not grown, but } \\
\text { sold }\end{array}$ & 5 & & & & & 1339 \\
\hline Total & 68 & & & & & 18647 \\
\hline
\end{tabular}

* Farms that grow medicinal plants

Source: Official site of the State Statistics Serviceof Ukraine (2019; http://www.ukrstat. gov.ua) authors" own depiction.

As the Table 3 shows in Ukraine, there are companies that do not produce medicinal plants, but are engaged in their sale. These are intermediary companies that buy raw materials from producers in order to form large export batches.

In $2018,43 \%$ of revenues from the sale of essential oil plants were received in Ukraine in the field of medicinal plant growing, $38 \%$ from the sale of purely medicinal plants, and $19 \%$ from the sale of spicy crops. Profitability of production according to the State Statistics Service of Ukraine in 2018 ranged from 5-100\% and reached a much higher level in some cases. The total value of sold products was 4.6 million dollars. USA (Fig. 1).

Mostly, medicinal plants grown in Ukraine are sold abroad. Most of them are exported to Poland, Germany and Bulgaria. Current trends indicate that the demand for medicinal herbs and their processing by European consumers will only increase in the future. This is due to the fact that European producers are gradually refusing to grow such products and are looking for suppliers in Ukraine. Accordingly, the margin of production of medicinal plants in Ukraine depends on both individual plants and demand from importing countries. Today, the structure of Ukrainian exports of medicinal plants by plant species is unbalanced, because a significant share is occupied by wild medicinal plants, in the almost complete absence of organic matter. This gives a competitive advantage to the United States and Europe, as there about $30 \%$ of the market for medicinal plants are organic. Although, it should be noted that Ukraine is also actively increasing the export of organic products, in the structure of which a significant share is accounted for by medicinal plants. Work in this direction is very promising, as for a long time the sale of products marked «organic» is more profitable (Duda, Mărghitaş, Dezmirean and Bobiş, 2015). 


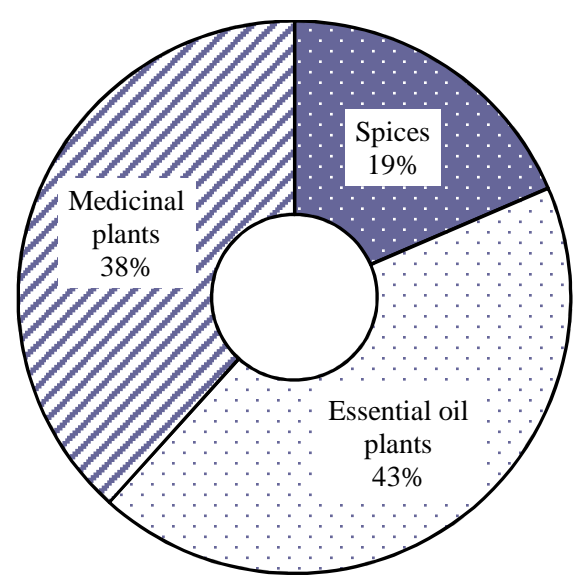

Fig. 1. Distribution of income from the sale of medicinal, spicy and essential oil plants, 2018

Source: ownstudy.

It should be noted that the structure of exports and imports of medicinal plants by species both in Ukraine and in the world is not something stable and permanent. The need for raw materials of a certain type depends on the provision of it in the previous period and the general trends in the consumption of medicinal plants. For example, in the CIS today, the consumption of medicinal plants is declining due to impoverishment, and in Germany increasing due to the promotion of a healthy lifestyle. Export-import volumes and, accordingly, prices for medicinal plants depend on weather conditions, the world harvest and trends in the needs of processing enterprises.

\section{CONCLUSION}

In general, the study of the current state of production of medicinal plants in Ukraine showed the following. The branch of medicinal plant growing in Ukraine has a significant production potential, and the production of medicinal plants in today's conditions is economically feasible. First, there is a set of producers in this area. It is represented by large, medium, small and small-scale enterprises. The study found that the volume of production of medicinal plants (excluding essential oils and spices) are led by large enterprises with sown areas of more than 100 hectares, and the level of yield with a small gap in 2018, the leaders were small-scale enterprises. This suggests that there are large specialized enterprises in the industry, which probably have the best capacity for production, drying and finishing of raw materials. Accordingly, this means that large enterprises producing medicinal plants can achieve highterhigher quality products. Second, large enterprises that produce large quantities of medicinal plants can offer processors, pharmaceutical factories and intermediaries large batches of quality products, for which buyers give ahigher price. The presence of small enterprises in the field of medicinal plant growing, namely family farms, in turnindicates the development of small business. This can also be seen as an advantage, as small businesses in rural areas contribute to employment and are the backbone of the economy worldwide. 
Secondly, the evidence of the production potential of medicinal plant growing in Ukraine is that entrepreneurs in this industry diversify production in order to increase economic efficiency. Thus, in addition to purely medicinal plants, Ukrainian producers also grow their varieties - essential oils and spicy plants. In turn, each of the three groups has a wide range of cultures. With a wide range of products, Ukrainian manufacturers can respond quickly to changes in demand in the market of medicinal crops both in Ukraine and abroad.

Third, the economic feasibility of the production of medicinal plants in Ukraine is largely due to the export orientation of the industry and the significant demand for medicinal, essential oil and spice crops in many countries. Given the lack of financial resources for the development of a significant part of Ukrainian agricultural producers, medicinal crop production is also an attractive investment area for domestic and foreign capital.

Thus, the production of medicinal plants in today's conditions is an economically profitable and promising business that needs further development in Ukraine.

\section{REFERENCES}

Dachnytsia, D. (2018). Ryzykny pobavytysia travychkoiu: pro perspektyvy prodazhu likarskykh roslyn. Access on the internet: http://trk.dp.ua/.

Deina, D. (2019), «Svoia nisha» - yak Ukraina opynylasia v p’iatirtsi eksporteriv koriandru. Access on the internet: http://agravery.com/uk/posts/show/cvoa-nisa-ak-ukraina-opinilas-vpatirci-eksporteriv-koriandru

Argyropoulos, D. (2019). Plant-based medicinal and cosmetic products. Access on the internet: https://ec.europa.eu/eip/agriculture/sites/agri-eip/files/fg35_starting_paper_2019_en.pdf.

Hamilton, A.C. (2004). Medicinal plants, conservation and lively hoods. "Biodivers Conserv" Vol. 13:1.

Jafari, H., Ahmadian, M.A., Tarhani, A. (2017). Production of Medicinal Herbs, an Approach to Sustain the Rural Economy (Case Study: Villages in Ghochan County). "Journal of Research and Rural Planning” Vol. 6(1). DOI: 10.22067/jrrp.v6i1.56119.

Markytanenko, S. (2018). Efektyvni fermery chy neefektyvni ahrokholdynhy? Access on the internet: https://latifundist.com/193-efektivn-fermeri-chi-neefektivn-agroholdingi.

Mebrahtu, Hishe, Zemede, Asfaw, Mirutse, Giday (2016). Review on value chain analysis of medicinal plants and the associated challenges. Access on the internet: http://www. plantsjournal.com/archives/2016/vol4issue3/PartA/4-2-12.pdf

Mirzoieva, T.V. (2018). Osoblyvosti eksportu-importu produktsii likarskoho roslynnytstva $v$ umovakh sohodennia. „Biznes Inform” Vol. 7. Access on the internet: http://businessinform.net/pdf/2018/7_0/32_37.pdf

Mirzoieva, T.V. (2018). Shchodo pytannia ekonomichnoi efektyvnosti vyrobnytstva likarskykh roslyn i likarskoi roslynnoi syrovyny. „, Problemy ekonomiky” Vol. 3 (37). Access on the internet: http://www.problecon.com/export_pdf/problems-of-economy-2018-3_0-pages-267_272.pdf

Ovcharenko, M. (2017). Ukraina vkhodyt do TOP-5 svitovykh lideriv iz eksportu koriandru. Access on the internet: https://uprom.info/news/agro/ukrayina-vhodit-do-top-5-svitovih-liderivz-eksportu-koriandru/

Official site of the State Statistics Service of Ukraine. Access on the internet: http:// www.ukrstat.gov.ua 
Research Concerning the Economic Efficiency of Four Species of Medicinal Plants Grown in the Western Part of Transylvanian Plaine (2015) Simona Duda, Liviu Al. Mărghitaş, Dan Dezmirean and Otilia Bobiş. Access on the internet: http://journals.usamvcluj.ro/index. php/agriculture/article/view/11587/9442

Shabbara, M.H.M., Heba Y. AbdEL-Fatah, Karima, A., Mohamed and Haitham, B.A. Hassan (2017). Comparative economic study of production and marketing of Rosmarinus officinalis (Rosemary) between Arabic Republic of Egypt and India. Access on the internet: http://www.curresweb.com/mejar/mejar/2017/1045-1048.pdf

Shi-Lin Chen, Hua Yu, Hong-Mei Luo, Qiong Wu, Chun-Fang Li, Steinmetz, A. (2016). Conservation and sustainable use of medicinal plants: problems, progress, and prospects. Access on the internet: https://cmjournal.biomedcentral.com/articles/10.1186/s13020-016-0108-7

Sri. Astutik, Jürgen Pretzschand Jude Ndzifon Kimengsi (2019). Asian Medicinal Plants' Production and Utilization Potentials. Access on the internet: ///C:/Documents\%20and\% 20Settings/User/Мои\%20документы/Downloads/sustainability-11-05483-v2.pdf

Stelter, W., Oehme, F., Daebeler, S. (2017). Vorstellung der Besonderheiten des Arzneipflanzenanbaus und Förderaktivitäten des Bundesministeriums für Ernährung und Landwirtschaft (BMEL) [In:] 3. Tagung Arzneipflanzenanbau in Deutschland - mit koordinierter Forschung zum Erfolg, Schweinfurt, Germany, June 20-21.

Yebirzaf, Yeshiwas (2018). The dynamics of medicinal plants utilization practice nexus its health and economic role in Ethiopia. Access on the internet: https://www.researchgate. net/publication/331123936_the_dynamics_of_medicinal_plants_utilization_practice_nexus_its _health_and_economic_role_in_ethiopia_a_review_paper.

DOI: $10.7862 /$ rz.2020.mmr.14

The text was submitted to the editorial office: May 2020.

The text was accepted for publication: June 2020. 